\title{
PEMETAAN LAHAN PERTANIAN MENGGUNAKAN SISTEM INFORMASI GEOGRAFI (SIG) TERHADAP TINGKAT KETAHANAN PANGAN DI KABUPATEN INDRAMAYU
}

\author{
Syaripulloh, Iwan Purwanto, Masruroh, Imam Munandar \\ UIN Syarif Hidayatullah Jakarta, Indonesia \\ E-mail: syarifibnuhasby@gmail.com
}

\begin{abstract}
Meeting the needs of the diverse agricultural sector from various agricultural subsectors is a challenge for the government at this time, mapping of food security must be applied to overcome these problems. As for the indicators of the level of food security according to the FSVA (A Food Security and Vulnerability Atlas) of Indonesia 2015, live below the poverty line, Percentage of villages with inadequate access to links, Percentage of households without access to electricity, Percentage of women over 15 years who cannot read or write, Percentage of households without access to clean water, Percentage of villages with distance greater than $5 \mathrm{~km}$ from health facilities, Toddlers with poor nutrition, Life expectancy at birth, this must be fully supported by various parties. The role of GIS applications in the analysis of food security levels is in the processing of data indicators / parameters of the level of food security overlapped into a map of food security levels. The purpose of this study was to analyze the dominant factors of food security parameters that affect the level of food security in Indramayu Regency.
\end{abstract}

Keywords: food security indicators; geographic information systems; regression analysis

Abstrak. Pemenuhan kebutuhan dari sektor pertanian yang beranega ragam dari berbagai subsektor pertanian menjadi tantangan pemerintah saat ini, pemetaan ketahanan pangan harus diterapkan guna mengatasi masalah tersebut adapun indikator tingkat ketahanan pangan menurut FSVA (A Food Security and Vulnerability Atlas) of Indonesia 2015 adalah, Persentase penduduk yang hidup di bawah garis kemiskinan, Persentase desa dengan akses penghubung yang kurang memadai, Persentase rumah tangga tanpa akses listrik, Persentase perempuan di atas 15 tahun yang tidak dapat membaca atau menulis, Persentase rumah tangga tanpa akses ke air bersih, Persentase desa dengan jarak lebih dari $5 \mathrm{~km}$ dari fasilitas kesehatan, Balita dengan gizi buruk, Angka harapan hidup pada saat lahir, hal ini harus didukung sepenuhnya oleh berbagai pihak. Peran aplikasi SIG dalam analisis tingkat ketahanan pangan yaitu dalam pengolahan data indikator/parameter tingkat ketahanan pangan yang ditumpang susunkan (overlay) menjadi peta tingkat ketahanan pangan. Tujuan penelitian ini untuk menganalisis faktor dominan dari parameter ketahanan pangan yang mempengaruhi tingkat ketahanan pangan di Kabupaten Indramayu.

Kata Kunci: indikator ketahanan pangan; sistem informasi geografi; analisis regresi

Permalink/DOI: https://doi.org/10.15408/mimbar.v36i2. 


\section{Pendahuluan}

Di Indonesia sendiri yang memiliki penduduk 248 juta jiwa yang tersebar di lebih dari 13,400 pulau, Indonesia menduduki peringkat keempat untuk negara dengan penduduk terbanyak di dunia (BPS, 2014). Pertumbuhan penduduk tahunan dalam dekade terakhir mencapai rata-rata 1,5 persen, meskipun terjadi pengurangan yang signifikan pada jumlah anak yang lahir, jumlah penduduk diperkirakan akan mencapai 306 juta pada tahun 2035 (BPS, 2013).

Indonesia juga merupakan negara dengan peringkat ke-16 untuk perekonomian terbesar di dunia, meskipun pertumbuhan ekonomi baru-baru ini menunjukkan tanda-tanda penurunan, dengan perkiraan pertumbuhan ekonomi sebesar 5,2 persen di tahun 2015 (World Bank, 2014), maka Indonesia sebagai bangsa harus memenuhi kebutuhan pangan rakyatnya dan memikirkan Kedaulatan pangan yang diterjemahkan dalam bentuk kemampuan bangsa dalam hal: (1) mencukupi kebutuhan pangan dari prosukdi dalam negeri, (2) mengatur kebijakan pangan secara mandiri, serta (3) melindungi dan menyejahteraan petani sebagai palaku utama usaha pertanian pangan. (Dalam Kementrian Pertanian Indonesia Renstra 2015-2019)

Menyikapi hal tersebut pemenuhan kebutuhan dari sektor pertanian terutama kebutuhan pangan dan kaitannya dengan itu serta kesejahteraan petani yang tidak dapat dipisahkan merupakan pekerjaan rumah pemerintah yang wajib diselesaikan. Dari Total daratan Indonesia $1.922 .570 \mathrm{~km}^{2}$ atau setara dengan 192.257.000 hektar dengan total lahan pertanian sawah di tahun 2012 adalah 7.662.554 hektar. (Dalam Kementrian Pertanian Indonesia Renstra 2015-2019)

Dari total lahan pertanian tersebut dengan berbagai macam komoditas pertanian di Indonesia pemerintah masih mengandalkan impor dalam pemenuhan kebutuhan pangan dalam negerinya terutama pada tanaman pangan. Bila dilihat dari subsektor, kondisi Komoditas perdagangan pangan Indonesia pada posisi difisit atau dengan kata lain bahwa Indonesia menjadi negara net importer kecuali subsektor perkebunan dan holtikulturan dengan neraca perdagangan sebagai berikut:

Tabel 1. Neraca Perdagangan Sektor Pertanian Tahun 2010-2014

\begin{tabular}{|c|c|c|c|c|c|c|}
\hline \multirow[t]{2}{*}{ No } & \multirow[t]{2}{*}{ Sub Sektor } & \multicolumn{5}{|c|}{ Tahun (Juta US\$) } \\
\hline & & 2010 & 2011 & 2012 & 2013 & 2014 \\
\hline \multirow[t]{4}{*}{1} & Tanaman Pangan & \multicolumn{5}{|c|}{ Ekspor - Impor $=$ Neraca } \\
\hline & Ekspor & 478 & 585 & 151 & 967 & 560 \\
\hline & Impor & 3.894 & 7.024 & 6.307 & 5.659 & 6.481 \\
\hline & Neraca & -3.416 & -6.439 & -6.156 & -4.629 & -5.921 \\
\hline \multirow[t]{4}{*}{2} & Hortikultural & \multicolumn{5}{|c|}{ Ekspor - Impor $=$ Neraca } \\
\hline & Ekspor & 391 & 491 & 505 & 784 & 752 \\
\hline & Impor & 1.293 & 1.686 & 1.813 & 1.469 & 1.929 \\
\hline & Neraca & -902 & -1.195 & -1.309 & -685 & -1.176 \\
\hline \multirow[t]{4}{*}{3} & Perkebunan & \multicolumn{5}{|c|}{ Ekspor - Impor $=$ Neraca } \\
\hline & Ekspor & 30.703 & 40.690 & 33.119 & 30.687 & 37.123 \\
\hline & Impor & 6.028 & 8.884 & 3.112 & 2.686 & 5.926 \\
\hline & Neraca & 24.675 & 31.846 & 30.007 & 28.002 & 31.197 \\
\hline \multirow[t]{4}{*}{4} & Peternakan & \multicolumn{5}{|c|}{ Ekspor - Impor $=$ Neraca } \\
\hline & Ekspor & 494 & 907 & 557 & 1.243 & 1.330 \\
\hline & Impor & 1.232 & 1.191 & 2.698 & 3.015 & 3.029 \\
\hline & Neraca & -737 & -284 & -2.142 & -1.772 & -1.699 \\
\hline
\end{tabular}


MIMBAR Agama Budaya, 36 (2), 2019

\begin{tabular}{|c|c|c|c|c|c|c|}
\hline \multirow[t]{2}{*}{ No } & \multirow[t]{2}{*}{ Sub Sektor } & \multicolumn{5}{|c|}{ Tahun (Juta US\$) } \\
\hline & & 2010 & 2011 & 2012 & 2013 & 2014 \\
\hline & Total Pertanian & \multicolumn{5}{|c|}{ Ekspor - Impor $=$ Neraca } \\
\hline & Ekspor & 32.065 & 42.673 & 34.331 & 33.680 & 39.765 \\
\hline & Impor & 12.447 & 18.744 & 13.931 & 12.828 & 17.365 \\
\hline & Neraca & 19.619 & 23.928 & 20.400 & 20.852 & 22.400 \\
\hline
\end{tabular}

Sumber: BPS (diolah Ditjen PPHP), 2016

Selain masih mengandalkan impor dalam pemenuhan kebutuhan pangan nasional Indonesia juga masih kesulitan dalam pengendalian harga pangan, terutama subsektor pertanian tanaman pangan, dalam tabel diatas terlihat jelas kebijakan impor masih menjadi andalan untuk menutupi kekurangan kebutuhan pangan nasional.

Dalam upaya meningkatkan ketahanan pangan dan gizi, sangat penting untuk memahami tentang siapa dan berapa banyak yang rentan terhadap kerawanan pangan dan gizi, di mana mereka tinggal dan apa yang membuat mereka rentan. Sejak tahun 2003, Pemerintah Indonesia bekerja sama dengan salah satu badan Perserikatan Bangsa-Bangsa, World Food Programme (WFP), untuk memperkuat pemahaman ini melalui pengembangan peta ketahanan pangan dan gizi. Peta ini berfungsi sebagai alat yang ampuh untuk meningkatkan pencapaian sasaran dan memberi informasi kepada proses pembuatan kebijakan di bidang ketahanan pangan dan gizi. (Imam Mahdi, Sp. MM. Kabid Analisis Ketahanan Pangan dalam wawancara)

Pada tahun 2009, metodologi Peta Ketahanan dan Kerentanan Pangan telah disempurnakan dengan cakupan yang diperluas menjadi 346 kabupaten di 32 provinsi. Hasil dari FSVA 2009 memberikan kontribusi langsung terhadap perubahan kebijakan penting termasuk integrasi kegiatan yang berhubungan dengan ketahanan pangan dan gizi ke dalam rencana dan alokasi anggaran tahunan pemerintah. Selain itu, keberhasilan FSVA 2009 juga mendorong diadakannya pelatihan-pelatihan bagi para staff teknis provinsi oleh Badan Ketahanan Pangan (BKP) dan WFP dalam bidang analisis ketahanan pangan dan gizi yang kemudian dilakukan penyusunan peta FSVA di seluruh provinsi yang dirilis dari tahun 2011 sampai tahun 2013.

Upaya pemerintah dalam hal ketahanan pangan ini telah dirumuskan Presiden Joko Widodo dalam Sembilan Agenda Prioritas (Nawa Cita) pada bulan Oktober 2014, yang salah satunya menekankan kedaulatan pangan sebagai prinsip untuk mencapai ketahanan pangan. Hal ini kemudian dituangkan ke dalam kebijakan yang tercantum dalam Rencana Pembangunan Jangka Menengah Nasional (RPJMN) 2015-2019. Arah kebijakan dan sasaran prioritas utama yang berkaitan dengan kedaulatan pangan di lakukan dengan lima strategi utama, meliputi: (WFT : 2015)

1. Peningkatan ketersediaan pangan melalui penguatan kapasitas produksi dalam negeri, yang meliputi komoditas padi, jagung, kedelai, daging, gula, cabai dan bawang merah.

2. Peningkatan kualitas distribusi pangan dan aksesibilitas masyarakat terhadap pangan.

3. Perbaikan kualitas konsumsi pangan dan gizi masyarakat. 
4. Perlindungan ketahanan pangan dilakukan melalui kesiapsiagaan mengantisipasi bencana alam,mitigasi dampak perubahan iklim dan serangan organisme tanaman dan penyakit hewan.

5. Peningkatan kesejahteraan petani, nelayan dan pelaku utama penghasil bahan pangan lainnya.

Menilik dari permasalah diatas, pemenuhan kebutuhan dari sektor pertanian yang beranega ragam dari berbagai subsektor pertanian menjadi tantangan pemerintah saat ini, pemetaan ketahanan pangan harus diterapkan guna mengatasi masalah tersebut adapun indikator tingkat ketahanan pangan menurut FSVA (A Food Security and Vulnerability Atlas) of Indonesia 2015 adalah, Persentase penduduk yang hidup di bawah garis kemiskinan, Persentase desa dengan akses penghubung yang kurang memadai, Persentase rumah tangga tanpa akses listrik, Persentase perempuan di atas 15 tahun yang tidak dapat membaca atau menulis, Persentase rumah tangga tanpa akses ke air bersih, Persentase desa dengan jarak lebih dari $5 \mathrm{~km}$ dari fasilitas kesehatan, Balita dengan gizi buruk, Angka harapan hidup pada saat lahir, hal ini harus didukung sepenuhnya oleh berbagai pihak, terutama para petani yang secara langsung berhadapan dengan pangan dan ketahanan pangan tetapi penurunan minat pekerja di bidang pertanian, pemuda saat ini terutama pada usia angkatan kerja setelah mereka lulus sekolah menengah atau perguruan tinggi lebih memilih bekerja di sektor selain pertanian, bisa dilihat pada grafik dibawah ini:

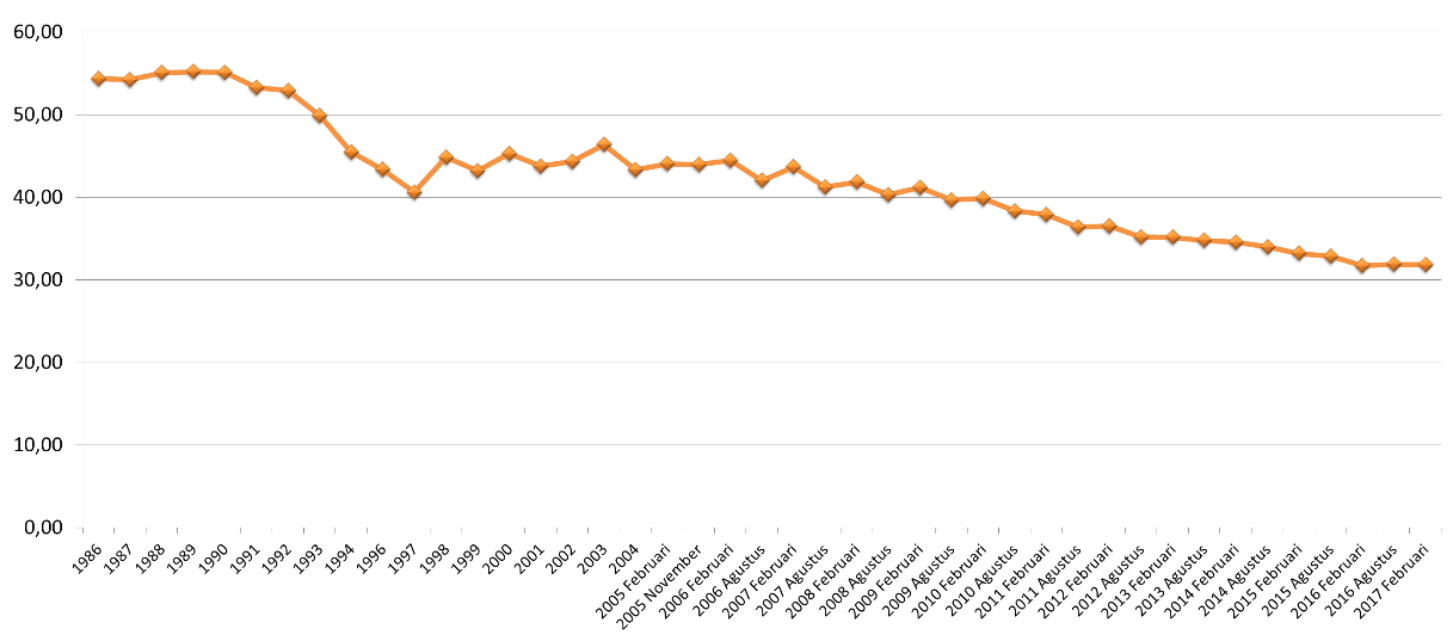

Sumber: Sakernas BPS (www.bps.go.id), 2017

Grafik 1. Persentase Penduduk 15 Tahun Keatas yang Bekerja di Sektor Pertanian (meliputi Lapangan Usaha Pertanian, Perkebunan, Kehutanan, Perburuan, dan Perikanan)

Dari grafik diatas terlihat jelas penurunan yang bekerja di sektor pertanian semakin tahun semakin menurun, dari tahun 1986 sampai 2017 walaupun penurunnya tidak signifikan akan tetapi tran seperti ini akan berlanjut jika pemerintah selaku pemegang kebijakan tidak segera mengambil langkah, terutama bagaimana mensejahterakan petani yang menjadi penggerak utama sumber pangan Indonesia.

Dengan demikan informasi mengenai tingkat ketahanan pangan di suatu wilayah sangat penting untuk diketahui, sehingga untuk mempermudah mendapat informasi persebaran tingkat ketahanan 
pangan dapat menggunakan analisis Sistem Informasi Geografis (SIG). Peran aplikasi SIG dalam analisis tingkat ketahanan pangan yaitu dalam pengolahan data indikator/parameter tingkat ketahanan pangan yang ditumpang susunkan (overlay) menjadi peta tingkat ketahanan pangan. Peta tingkat ketahanan pangan yang dihasilkan bersifat spasial/ keruangan, sehingga penyajian dalam bentuk peta ini akan lebih memudahkan dalam membaca informasi tingkat ketahanan pangan. Rumusan Masalah pada penelitian ini adalah : "Bagaimana Persebaran Pemetaan Tingkat Ketahanan Pangan di Kabupaten Indramayu?"

\section{Metode}

Metode yang digunakan dalam penelitian ini yaitu kuantitaif dengan pendekatan deskriptif. Penelitian ini bertempat di Kabupaten Indramayu Jawa Barat, pengumpulan data penelitian ini dilaksanakan bulan Juni - September 2018. Sampel yang di pakai yaitu non-probality sample peneliti menggunakan teknik purposive sampling, dimana berdasarkan adanya pertimbangan tertentu dan tujuan yang ingin dicapai. Dalam pengambilan sampel peneliti mengambil seluruh kecamatan di Kabupaten Indramayu yaitu 31 Kecamatan.sesuai dengan tujuan yang ingin dicapai dalam Indikator Badan Ketahanan Pangan Nasional Republik Indonesia.

\section{Hasil dan Pembahasan}

\section{Pengolahan data indicator FSVA Menggunakan ArcGis}

Pengolahan data yang digunakan sesuai dengan standar indikator/parameter FSVA (A Food Security and Vulneralility Atlas) atau Peta Ketahanan Pangan Indonesia, hasil pengolahan parameter ketahanan pangan antara lain:

\section{Rasio Konsumsi Normatif Perkapita terhadap Produksi Pangan (X1)}

Hasil pengkelasan berdasarkan FSVA (A Food Security and Vulnerability Atlas) of Indonesia, dari 21 kecamatan yang ada di Kabupaten Indramayu, hanya satu kecamatan masuk ke dalam kategori surplus sedang, yaitu Kecamatan Indramayu dengan rasio konsumsi normatif sebesar 0,65. Kecamatan lainnya termasuk dalam kategori surplus tinggi yang memiliki nilai rasio antara $0-<0,5$ yaitu, Kecamatan Haurgeulis, Gantar, Kroya, Gabuswetan, Cikedung, Terisi, Lelea, Bangodua, Tukdana, Widasari, Kertasmaya, Sukagumiwang, Krangkeng, Karangampel, Kedokan Bunder, Juntinyuat, Sliyeg, Jatibarang, Sindang, Cantigi, Pasekan, Lohbener, Arahan, Losarang, Kandanghaur, Bongas, Anjatan, Sukra, dan Patrol. 


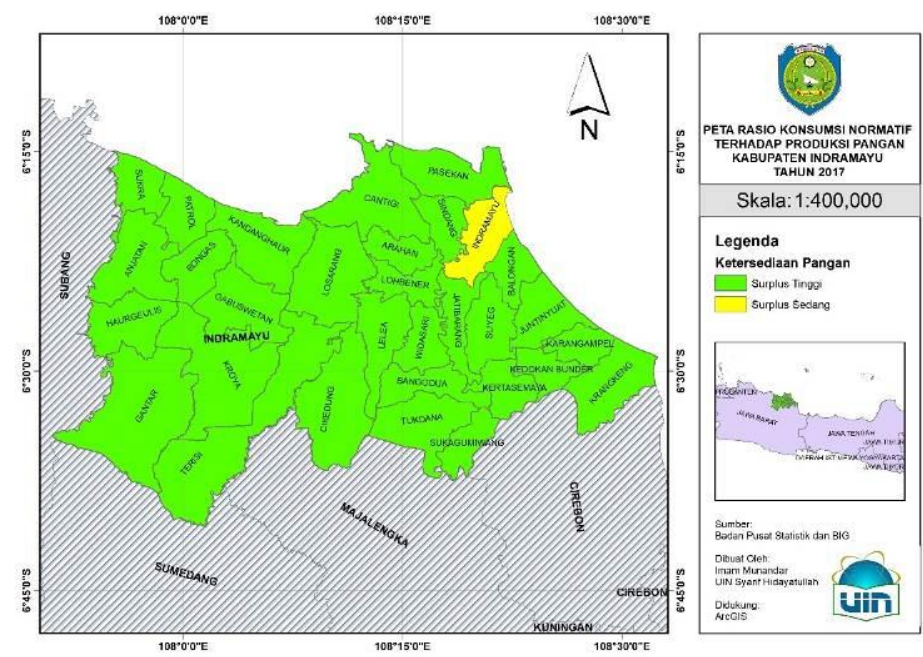

Gambar 1. Peta Rasio Konsumsi Normatif Perkapita Terhadap Produksi Pangan Kabupaten Indramayu Tahu 2017

\section{Persentase Penduduk di Bawah Garis Kemiskinan (X2)}

Parameter ini menunjukan ketidakmampuan dalam mengakses pangan secara baik karena rendahnya daya beli. Representasi peta penduduk di bawah garis kemiskinan ditunjukkan oleh warna hijau dan kuning, secara keseluruhan, penduduk Kabupaten Indramayu dari total penduduk 1.728.050 jiwa memiliki penduduk dibawah garis kemiskinan sebanyak 386.124 jiwa (kriteria penduduk dibawah garis kemiskinan penduduk pra sejahtera dan sejahera I menurut dinas kesehatan kabupaten Indramayu) atau 22,34\% dari seluruh penduduk Kabupaten Indramayu, adapun persentase penduduk dibawah garis kemiskinan yang sangat rendah berada pada kecamatan Indramayu dan Kecamatan Sindang sebanyak 18,92\% dan 16,36\% , dan 29 kecamatan lainnya dalam ketegori rendah yaitu 20\%-29\%.

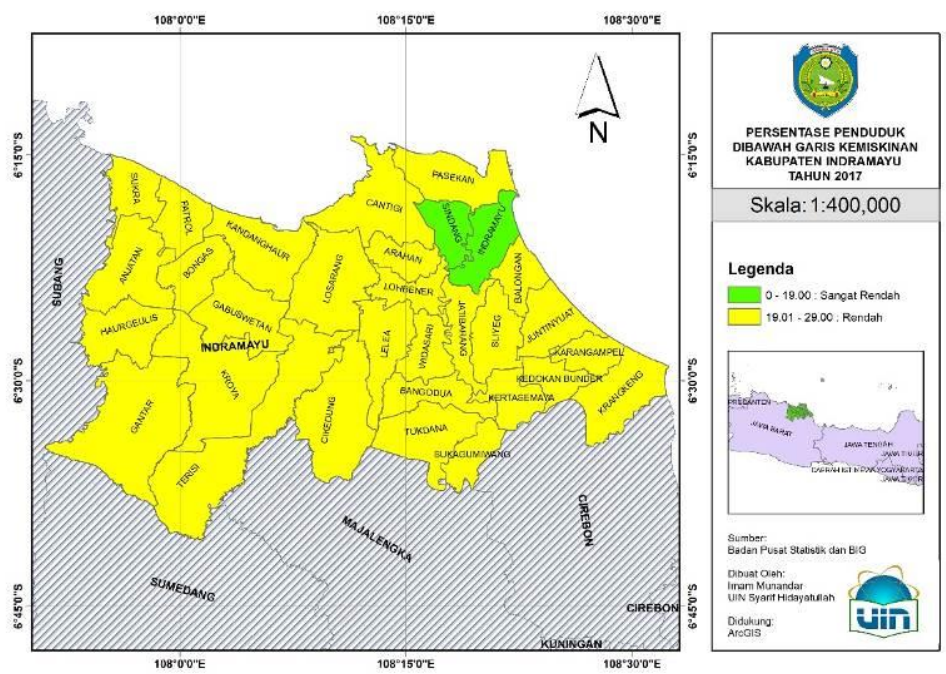

Gambar 2. Peta Persentase Penduduk dibawah Garis Kemiskinan Kabupaten Indramayu Tahun 2017 


\section{Persentase Desa Dengan Akses Penghubung yang Kurang Memadai (X3)}

Persendase desa dengan akses penghubung yang kurang memadai diperoleh dari jalan desa yang rusak berat dibagi dengan jumlah total jalan dalam kilo meter, persentase desa dengan akses penghubung yang kurang memadai diperoleh perkecamatan. 31 kecamatan di Kabupaten Indramayu mengalami kerusakan jalan ringan rentan yaitu $0-9 \%$ dan dalam kategoru sangat rendah tercatat persentase desa dengan akses yang kurang memadai paling rendah berada pada kecamatan Sindang sebesar 2,34\% dan yang tertinggi pada kecamatan Lelea

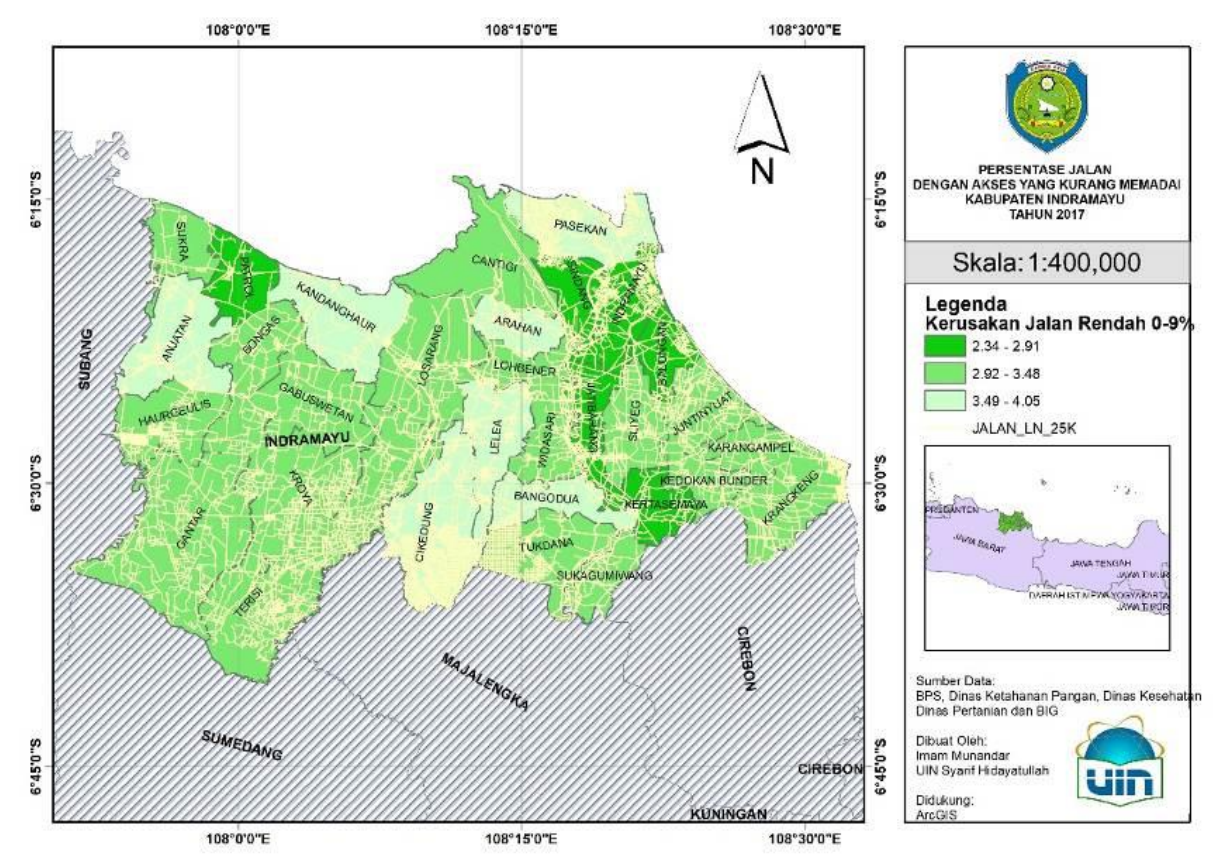

Gambar 3. Persentase Desa Dengan Jalan Yang Kurang Memadai Kerusakan Sangat Rendah 0 - 9\% Kabupaten Indramayu Tahun 2017

\section{Persentase Rumah Tangga Tanpa Akses Listrik (X4)}

Persentase penduduk tanpa akses listrik di Kabupaten Indramayu 31 kecamatan yang ada di Kabupaten Indramayu termasuk ke dalam kategori sangat rendah terhadap penduduk tanpa akses listrik, dengan persentase antara 0\% - <10\%. menurut data BPS Provinsi Jawa Barat rata-rata persentase penduduk tanpa akses listrik di Kabupaten Indramayu sebesar 0.82\%. Hal ini berarti 99,8\% penduduk sudah teraliri listrik dengan baik. selengkapnya dapat dilihat pada lampiran 4 . Persentase penduduk tanpa akses terhadap listrik sangat rendah dapat mempengaruhi kegiatan ekonomi yang akan semakin tinggi dengan adanya listrik yang dapat diakses masyarakat. Kegiatan ekonomi yang semakin tinggi akan membuka peluang yang lebih besar untuk akses pekerjaan. Peluang akses pekerjaan yang lebih besar akan meningkatkan tingkat kesejahteraan masyarakat Kabupaten Indramayu. 


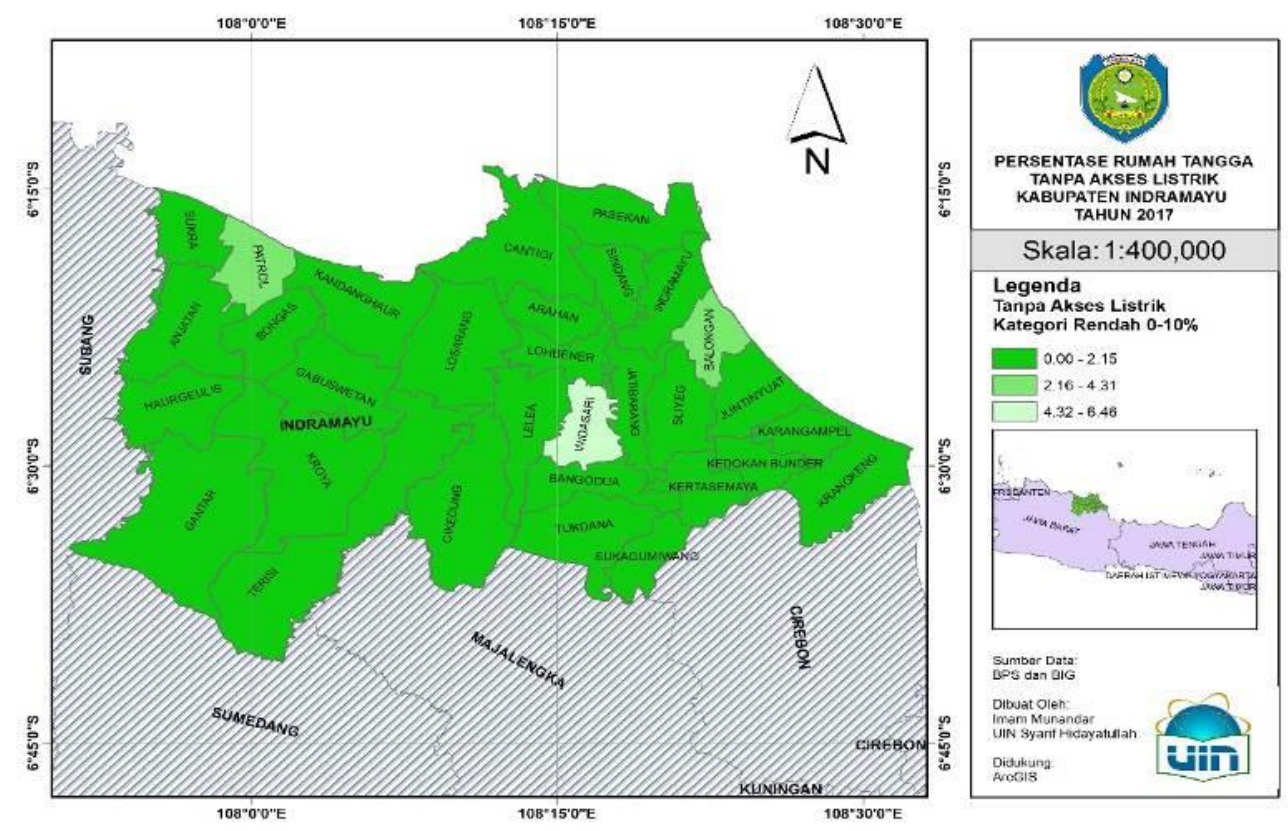

Gambar 4. Persentase Rumah Tangga Kategori Sangat Rendah Tanpa Akses Listrik 0-9\% Kabupaten Indramayu Tahun 2017

\section{Persentase Perempuan Buta Huruf (X5)}

Persentase perempuan buta huruf yang digunakan adalah data perkecamatan dengan ratarata persentase perempuan 15 Tahun keatas buta huruf di Kabupaten Indramayu pada tahun 2017 adalah 16\% meningkat dari tahun sebelumnya yang hanya 14\%. Parameter penduduk buta huruf berkenaan dengan tingkat pendidikan rata-rata yang dimiliki masyarakat. Penduduk buta huruf menunjukkan penduduk yang memiliki tingkat pendidikan rendah. Hal ini akan bedampak pada semakin terbatasnya pilihan pekerjaan yang dapat dipilih dan menyebabkan kecilnya kesempatan kerja yang diperoleh dibandingkan penduduk yang lebih terampil, sehingga hal tersebut akan mempengaruhi semakin lemahnya akses ekonomi masyarakat tersebut. Gambaran kecamatan dengan kriteria perempuan buta huruf sangat rendah, rendah, cukup rendah dan cukup tinggi terlihat pada peta dibawah ini. 


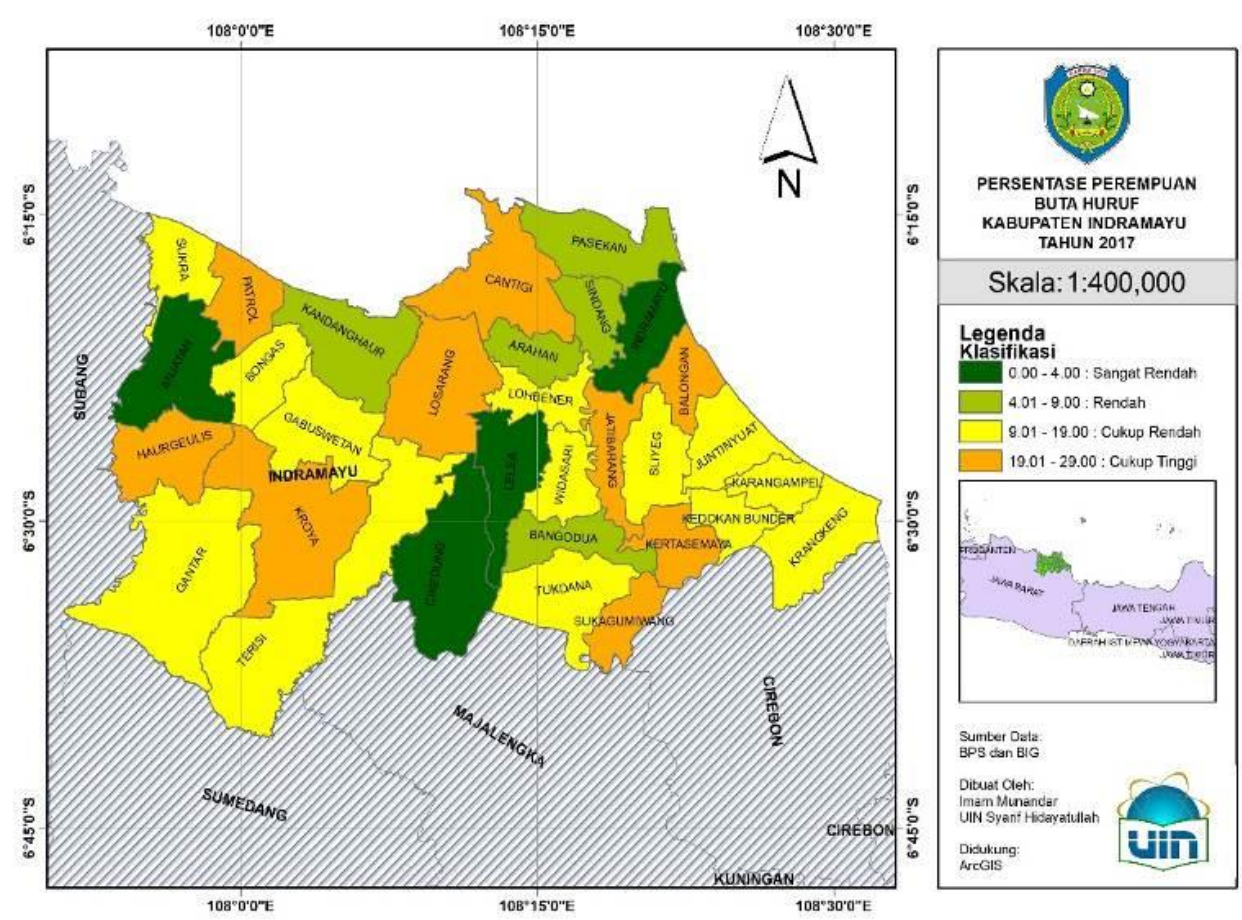

Gambar 5. Kriteria Persentase Perempuan 15 Tahun Keatas Buta Huruf Kabupaten Indramayu 2017

\section{Persentase Rumah Tangga Tanpa Akses ke Air Bersih (X6)}

Persentase penduduk tanpa akses air bersih di Kabupaten Indramayu yang digunakan adalah data perkecamatan dimana persentase penduduk tanpa akses air bersih tertinggi pada kecamatan Indramayu yaitu 6,48\% dan persentase terendah pada Kecamatan Pasekan sebesar $1,41 \%$, hal ini menunjukan bahwa sebagian besar penduduk Indramayu sudah mendapatkan akses air bersih.

\section{Persentase Desa Dengan Jarak Lebih Dari 5 Km Dari Fasilitas Kesehtan (X7)}

Hasil pengkelasan berdasarkan FSVA (A Food Security and Vulnerability Atlas) of Indonesia, dari data BPS bahwa setiap kecamatan memiliki fasilitas kesehatan, maka dari pada itu maka penulis merumuskan 31 kecamatan yang ada di Kabupaten Indramayu termasuk ke dalam kategori sangat rendah terhadap penduduk dengan akses ke fasilitas kesehatan $>5 \mathrm{~km}$, dengan rentang persentase antara $0 \%-<20 \%$. Tingkat akses ke fasilitas kesehatan $>5 \mathrm{~km}$ sangat rendah di semua kecamatan pada Kabupaten Indramayu menunjukkan bahwa semua kecamatan dapat terlayani oleh fasilitas kesehatan. 


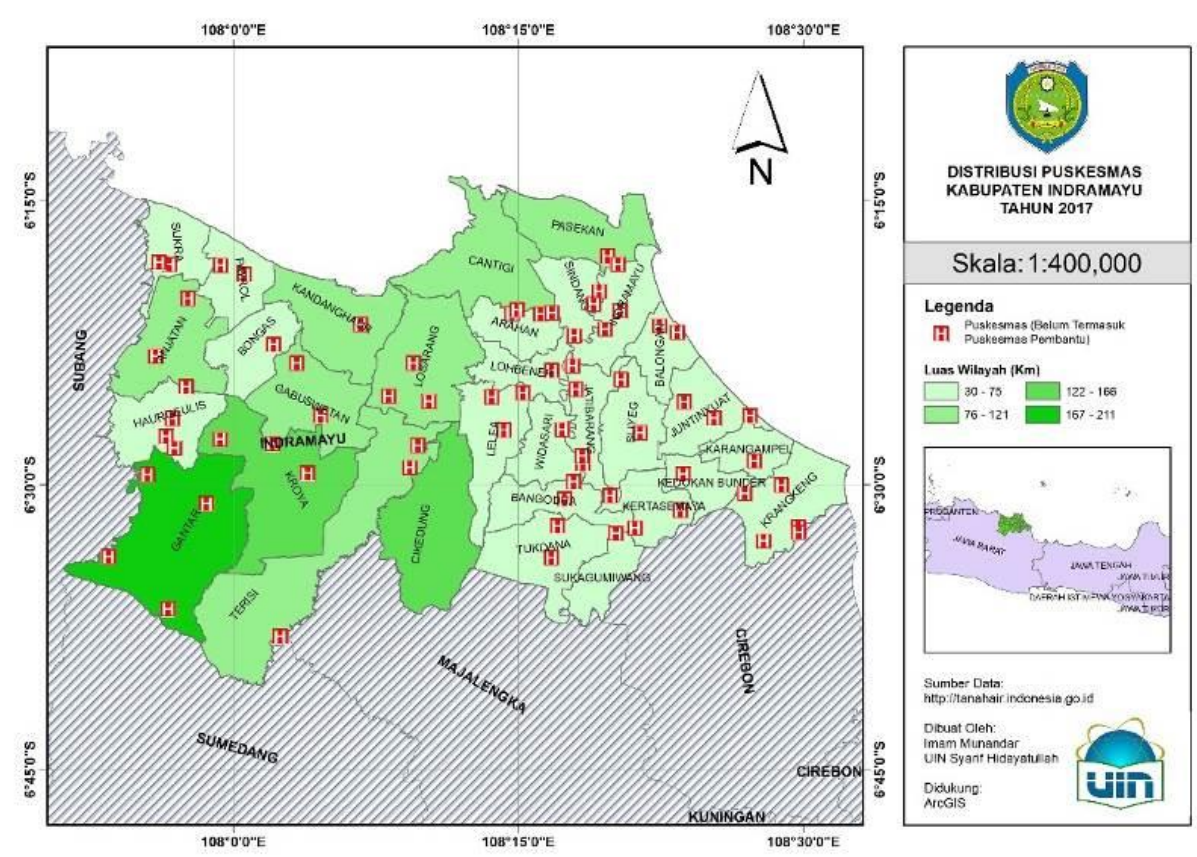

Gambar 7. Peta Distribusi Puskesmas Kabupaten Indramayu Tahun 2017

\section{Persentase Balita Gizi Buruk (X8)}

Hasil pengkelasan berdasarkan FSVA (A Food Security and Vulnerability Atlas) of Indonesia, dari data Dinas Ketahanan Pangan Kabupaten Indramayu menunjukan bahwa 31 kecamatan yang ada di Kabupaten Indramayu termasuk ke dalam kategori sangat rendah terhadap berat badan di bawah standar, dengan persentase antara $0 \%-9 \%$ yang termasuk kategori baik, tercatat status gizi buruk hanya ada pada kecamata Indramayu dan Kecamatan Sukagumiwang masing-masing 3,29\% dan 3,48\%. Berat badan balita yang baik/ standar akan mempengaruhi penyerapan/ absorbsi pangan yang baik juga. Hal tersebut juga akan berdampak pada status gizi balita yang juga akan tercukupi dengan baik. Status gizi balita yang tercukupi dengan baik akan mempengaruhi situasi ketahanan pangan, sehingga kondisi ketahanan pangan juga akan baik. adapun 31 kecamatan kategori sangat rendah pada rentang $0-9 \%$ akan dijelaskan pada maps dibawah ini. 


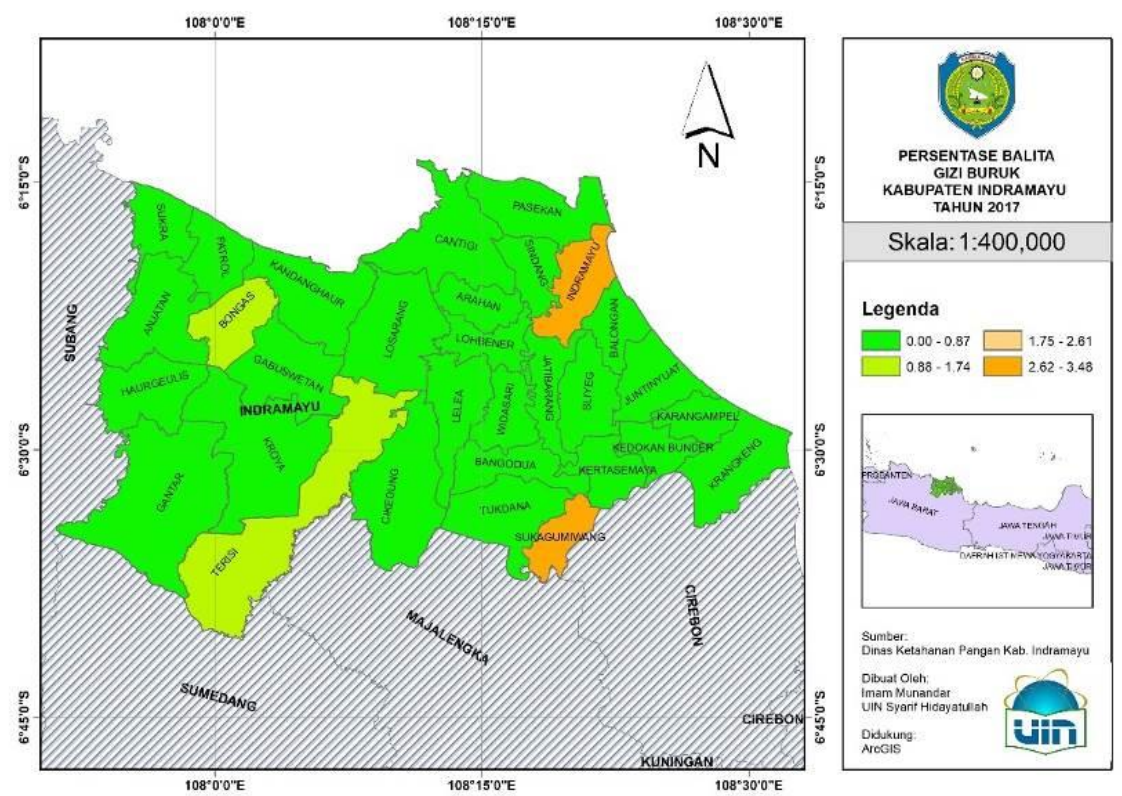

Gambar 8. Persentase Balita Gizi Buruk Kategori Sangat Rendah 0 - 9\% Kabupaten Indramayu Tahun 2017

\section{Angka Harapan Hidup (AHH) Pada Saat Lahir (X9)}

Data angka harapan hidup bermanfaat untuk melihat gambaran kesejahteraan penduduk dan tingkat derajat kesehatan. Angka harapan hidup saat lahir (AHH) di kabupaten Indramayu dari tahun 2010 - 2017 mengalami tren peningkatan hal tersebut menggambarkan tingkat kesehatan Kabupaten Indramayu yang terus membaik, pada tahun 2017 AHH Indramayu sebesar 70,86 Tahun.

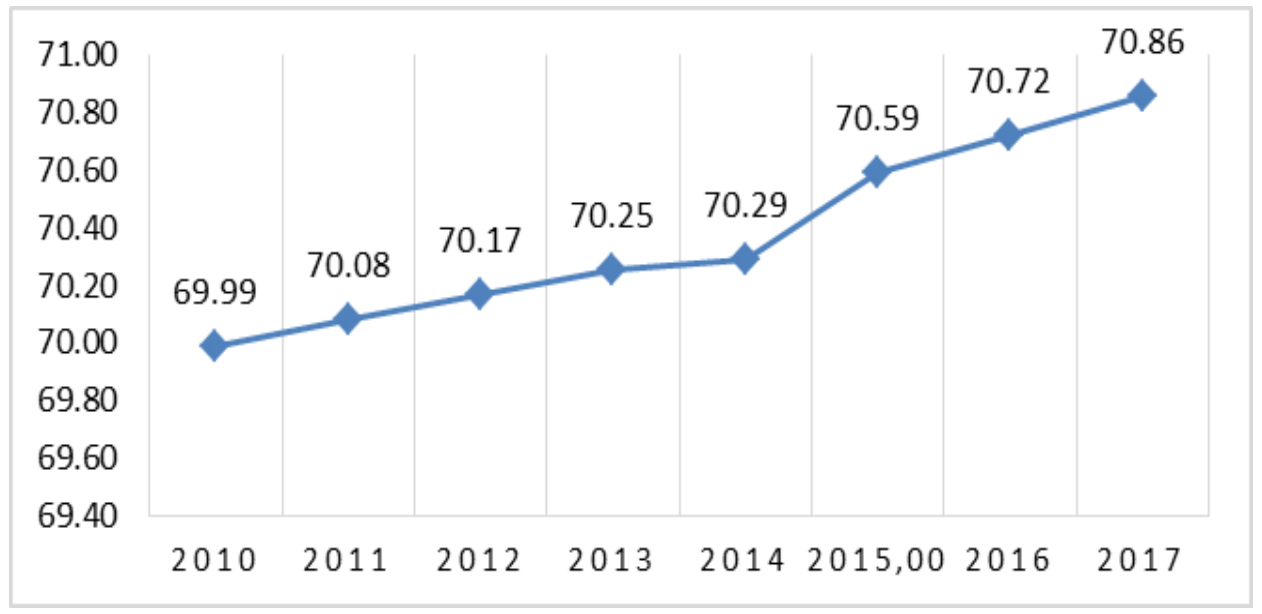

Sumber: BPS, Provinsi Jawa Barat, diolah kembali

Grafik 2. Angka Harpan Hidup (AHH) Pada Saat Lahir Kabupaten Indramayu Tahun 2010-2017 


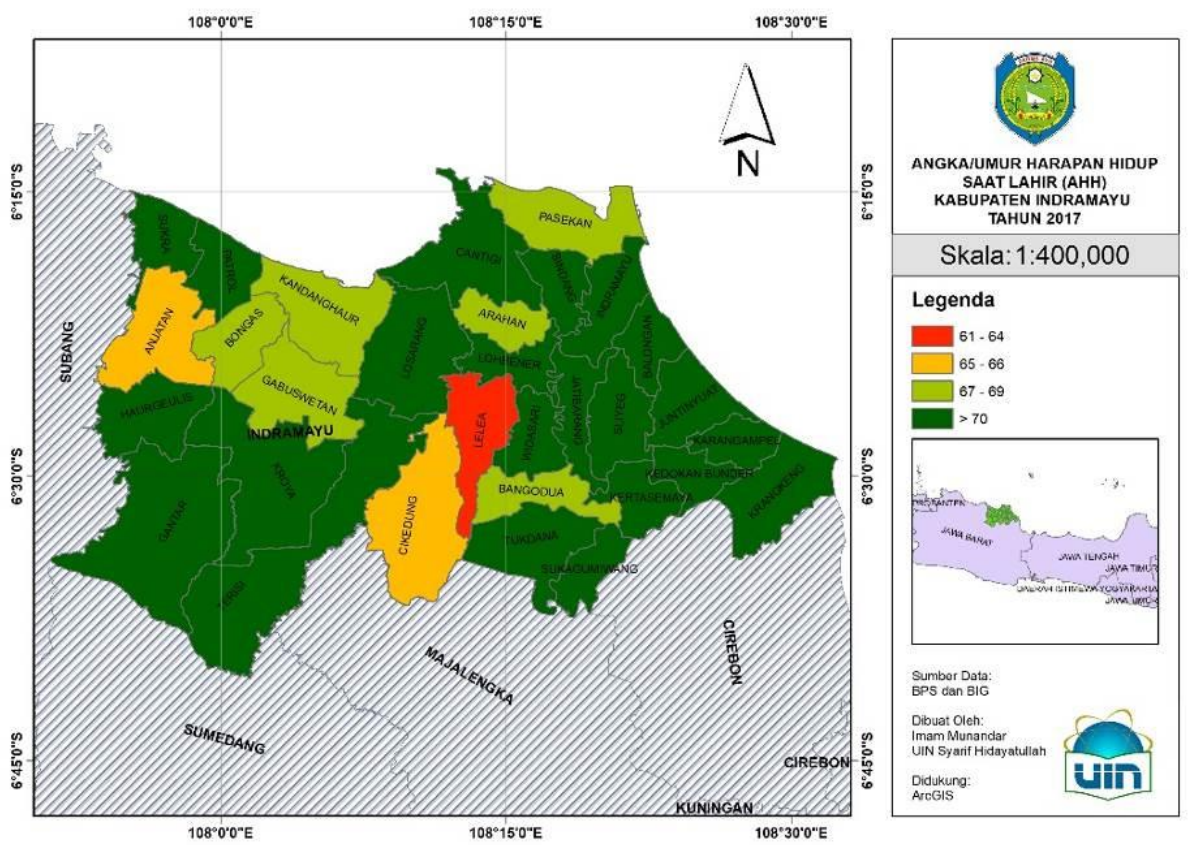

Gambar 9. Angka/Umur Harapan Hidup Saat Lahir Kabupaten Indramayu Tahun 2017

Data hasil pengolahan yang dikonversi ke dalam bentuk indeks, antara lain perhitungan Rasio konsumsi normatif per kapita terhadap ketersediaan bersih, Persentase penduduk yang hidup di bawah garis kemiskinan, Persentase desa dengan akses penghubung yang kurang memadai, Persentase rumah tangga tanpa akses listrik, Persentase perempuan di atas 15 tahun yang tidak dapat membaca atau menulis, Persentase rumah tangga tanpa akses ke air bersih, Persentase desa dengan jarak lebih dari $5 \mathrm{~km}$ dari fasilitas kesehatan, Balita dengan gizi buruk dan Angka harapan hidup pada saat lahir. Berikut hasil konversi parameter ketahanan pangan.

Tabel 2. Indeks Parameter Ketahanan Pangan dan Nilai Komposit Ketahanan Pangan Kabupaten Indramayu Tahun 2017

\begin{tabular}{llccccccccccc}
\hline NO & \multicolumn{1}{c}{ KECAMATAN } & \multicolumn{1}{c}{ Indeks Perameter } & \multicolumn{1}{c}{ K } \\
\cline { 3 - 10 } & & X1 & X2 & X3 & X4 & X5 & X6 & X7 & X8 & X9 & \\
$\mathbf{1}$ & HAURGEULIS & 0,33 & 0,34 & 0,34 & 0,00 & 0,62 & 0,77 & 0,50 & 0,00 & 0,66 & 0,42 \\
$\mathbf{2}$ & GANTAR & 0,02 & 0,52 & 0,52 & 0,04 & 0,42 & 0,43 & 0,17 & 0,01 & 0,48 & 0,31 \\
$\mathbf{3}$ & KROYA & 0,04 & 0,37 & 0,37 & 0,17 & 0,59 & 0,45 & 0,50 & 0,04 & 0,63 & 0,37 \\
$\mathbf{4}$ & GABUSWETAN & 0,06 & 0,66 & 0,66 & 0,00 & 0,26 & 0,36 & 0,33 & 0,00 & 0,34 & 0,31 \\
$\mathbf{5}$ & CIKEDUNG & 0,00 & 0,81 & 0,81 & 0,00 & 0,09 & 0,17 & 0,25 & 0,00 & 0,19 & 0,26 \\
$\mathbf{6}$ & TERISI & 0,05 & 0,59 & 0,59 & 0,19 & 0,35 & 0,34 & 0,17 & 0,36 & 0,41 & 0,35 \\
$\mathbf{7}$ & LELEA & 0,04 & 1,00 & 1,00 & 0,00 & 0,00 & 0,28 & 0,33 & 0,00 & 0,00 & 0,29 \\
$\mathbf{8}$ & BANGODUA & 0,06 & 0,78 & 0,78 & 0,26 & 0,13 & 0,04 & 0,17 & 0,06 & 0,22 & 0,28 \\
$\mathbf{9}$ & TUKDANA & 0,16 & 0,52 & 0,52 & 0,04 & 0,42 & 0,31 & 0,50 & 0,01 & 0,48 & 0,35 \\
$\mathbf{1 0}$ & WIDASARI & 0,14 & 0,60 & 0,60 & 1,00 & 0,33 & 0,11 & 0,50 & 0,23 & 0,40 & 0,45 \\
$\mathbf{1 1}$ & KERTASEMAYA & 0,25 & 0,24 & 0,24 & 0,00 & 0,73 & 0,42 & 0,25 & 0,00 & 0,76 & 0,35 \\
$\mathbf{1 2}$ & SUKAGUMIWANG & 0,16 & 0,33 & 0,33 & 0,06 & 0,63 & 0,15 & 0,50 & 1,00 & 0,67 & 0,45 \\
\hline
\end{tabular}


MIMBAR Agama Budaya, 36 (2), 2019

\begin{tabular}{llllllllllll}
\hline $\mathbf{1 3}$ & KRANGKENG & 0,19 & 0,57 & 0,57 & 0,13 & 0,36 & 0,46 & 0,25 & 0,03 & 0,43 & 0,35 \\
$\mathbf{1 4}$ & KARANGAMPEL & 0,48 & 0,59 & 0,59 & 0,30 & 0,35 & 0,45 & 0,00 & 0,07 & 0,41 & 0,37 \\
$\mathbf{1 5}$ & KEDOKANBUNDER & 0,25 & 0,47 & 0,47 & 0,04 & 0,48 & 0,24 & 0,25 & 0,01 & 0,53 & 0,32 \\
$\mathbf{1 6}$ & JUNTINYUAT & 0,23 & 0,56 & 0,56 & 0,17 & 0,37 & 0,63 & 0,33 & 0,04 & 0,44 & 0,39 \\
$\mathbf{1 7}$ & SLIYEG & 0,12 & 0,54 & 0,54 & 0,13 & 0,40 & 0,40 & 0,50 & 0,03 & 0,46 & 0,36 \\
$\mathbf{1 8}$ & JATIBARANG & 0,25 & 0,24 & 0,24 & 0,04 & 0,73 & 0,53 & 0,33 & 0,01 & 0,76 & 0,38 \\
$\mathbf{1 9}$ & BALONGAN & 0,38 & 0,33 & 0,33 & 0,43 & 0,63 & 0,17 & 0,50 & 0,10 & 0,67 & 0,42 \\
$\mathbf{2 0}$ & INDRAMAYU & 1,00 & 0,21 & 0,21 & 0,09 & 0,10 & 1,00 & 0,25 & 0,95 & 0,79 & 0,52 \\
$\mathbf{2 1}$ & SINDANG & 0,28 & 0,00 & 0,00 & 0,00 & 0,17 & 0,30 & 1,00 & 0,00 & 1,00 & 0,31 \\
$\mathbf{2 2}$ & CANTIGI & 0,20 & 0,36 & 0,36 & 0,13 & 0,60 & 0,09 & 0,25 & 0,03 & 0,64 & 0,32 \\
$\mathbf{2 3}$ & PASEKAN & 0,27 & 0,79 & 0,79 & 0,00 & 0,12 & 0,00 & 0,50 & 0,00 & 0,21 & 0,30 \\
$\mathbf{2 4}$ & LOHBENER & 0,23 & 0,49 & 0,49 & 0,00 & 0,45 & 0,35 & 0,50 & 0,00 & 0,51 & 0,35 \\
$\mathbf{2 5}$ & ARAHAN & 0,11 & 0,72 & 0,72 & 0,00 & 0,19 & 0,10 & 0,50 & 0,00 & 0,28 & 0,30 \\
$\mathbf{2 6}$ & LOSARANG & 0,06 & 0,34 & 0,34 & 0,00 & 0,62 & 0,34 & 0,33 & 0,00 & 0,66 & 0,32 \\
$\mathbf{2 7}$ & KANDANGHAUR & 0,21 & 0,76 & 0,76 & 0,04 & 0,15 & 0,72 & 0,50 & 0,01 & 0,24 & 0,38 \\
$\mathbf{2 8}$ & BONGAS & 0,14 & 0,65 & 0,65 & 0,08 & 0,27 & 0,26 & 0,33 & 0,44 & 0,35 & 0,36 \\
$\mathbf{2 9}$ & ANJATAN & 0,15 & 0,85 & 0,85 & 0,00 & 0,05 & 0,67 & 0,50 & 0,00 & 0,15 & 0,36 \\
$\mathbf{3 0}$ & SUKRA & 0,07 & 0,60 & 0,60 & 0,09 & 0,33 & 0,23 & 0,17 & 0,02 & 0,40 & 0,29 \\
$\mathbf{3 1}$ & PATROL & 0,18 & 0,27 & 0,27 & 0,48 & 0,69 & 0,36 & 0,17 & 0,11 & 0,73 & 0,39 \\
\hline
\end{tabular}

Keterangan: X1=Indeks Rasio konsumsi normatif per kapita terhadap ketersediaan bersih, X2=Indeks Persentase penduduk yang hidup di bawah garis kemiskinan, X3=Indeks Persentase desa dengan akses penghubung yang kurang memadai, X4=Indeks Persentase rumah tangga tanpa akses listrik, X5=Indeks Persentase perempuan di atas 15 tahun yang tidak dapat membaca atau menulis, X6=Indeks Persentase rumah tangga tanpa akses ke air bersih, X7=Indeks Persentase desa dengan jarak lebih dari $5 \mathrm{~km}$ dari fasilitas kesehatan, X8=Indeks Balita dengan gizi buruk, X9=Indeks Angka harapan hidup pada saat lahir, K=Nilai komposit tingkat ketahanan pangan

\section{Analisis Pemetaan Menggunakan Sisem Informasi Geografi (SIG) Terhadap Tingkat Ketahanan Pangan di Kabupaten Indramayu.}

Peta parameter ketahanan pangan terhadap tingkat ketahanan pangan memiliki range prioritas 6 (sangat tahan pangan) sampai dengan prioritas 1 (sangat rawan pangan) yang digambatkan dengan gradasi warna hijau tua digambarkan dengan prioritas 6 dan warna merah tua pada prioritas 1 . Gradasi warna prioritas tingkat ketahana pangan seperti gambar dibawah ini

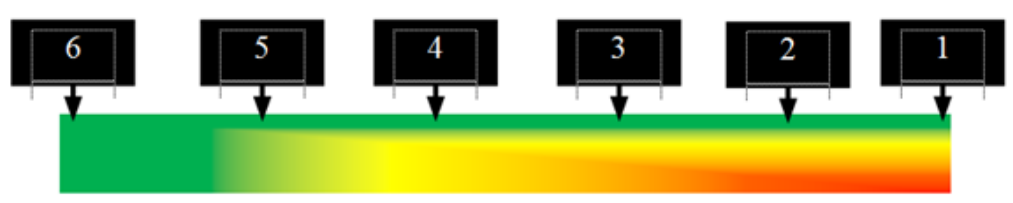

Gambar 1. Gradasi Warna Prioritas Tingkat Ketahanan Pangan 
Tidak ada Kecamatan dengan kategori sangat tahan pangan (prioritas 6). Kecamatan dengan kategori tahan pangan (prioritas 5) ada 11 kecamatan diantaranya, Kecamatan Sukra, Gantar, Gabuswetan, Losarang, Lelea, Bangodua, Kedokanbunder, Arahan, Cantigi, Sindang dan Pasekan ditandai dengan warna hijau. Sedangkan kecamatan yang masuk dalam kategori cukup tahan pangan (prioritas 4) ada 21 kecamatan diantaranya, Kecamatan Anjatan, Haurgeulis, Bongas, Patrol, Kandanghaur, Kroya, Terisi, Lohbener, Widasari, Tukdana, Sukagumiwang, Jatibarang, Sliyeg, Kertasemaya, Balongan, Juntinyuat, Karangampel, Krangkeng. sedangkan hanya ada 1 kecamatan yang masuk agak rawan pangan (prioritas 3) yaitu kecamatan Indramayu.

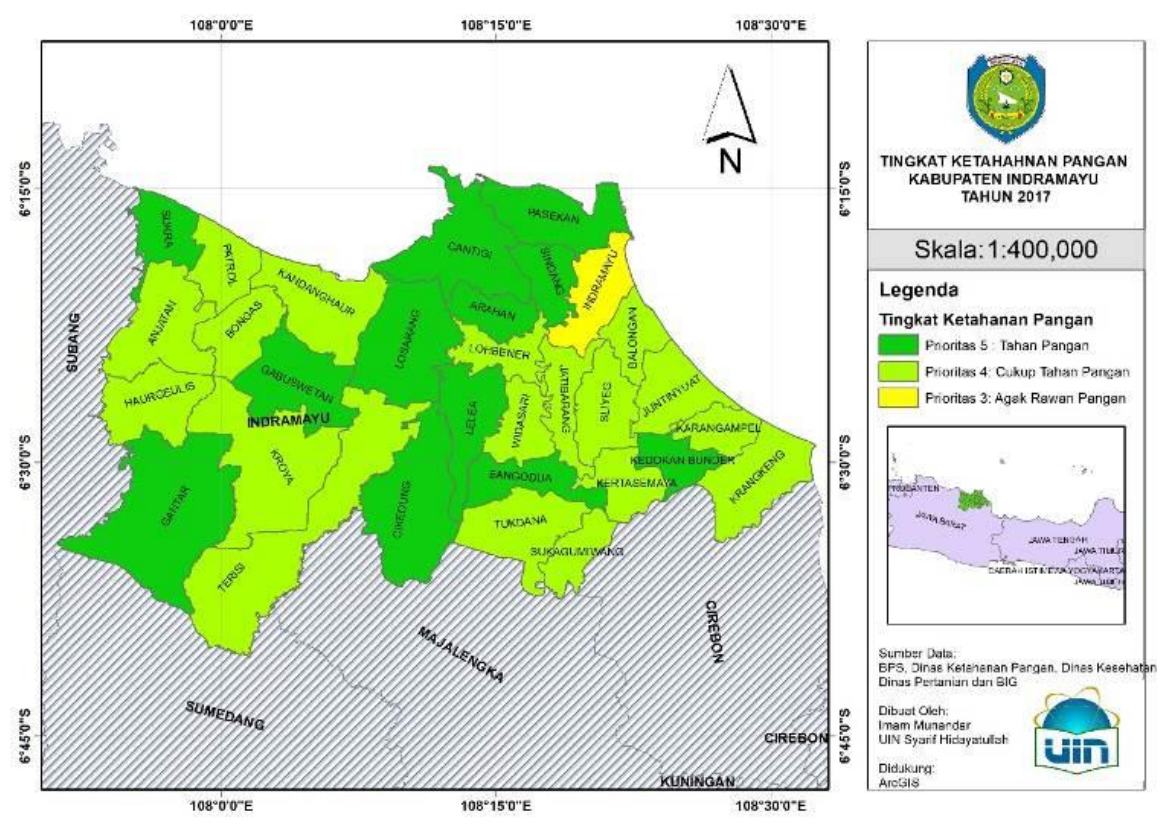

Gambar 11. Peta Tingkat Tetahanan Pangan Kabupaten Indramayu Tahun 2017 Skor Komposit dari Parameter Ketahanan Pangan Menggunakan Aplikasi ArcGis

\section{Penutup}

Dari analisis pemataan skor komposit ketahanan pangan menggunakan aplikasi ArcGis diperoleh hasil bahwa Kecamatan dengan kateori tahan pangan (prioritas 5) sebanyak 11 kecamatan diantaranya, Kecamatan Sukra, Gantar, Gabuswetan, Losarang, Lelea, Bangodua, Kedokanbunder, Arahan, Cantigi, Sindang dan Pasekan ditandai dengan warna hijau. Sedangkan kecamatan yang masuk dalam kategori cukup tahan pangan (prioritas 4) ada 21 kecamatan diantaranya, Kecamatan Anjatan, Haurgeulis, Bongas, Patrol, Kandanghaur, Kroya, Terisi, Lohbener, Widasari, Tukdana, Sukagumiwang, Jatibarang, Sliyeg, Kertasemaya, Balongan, Juntinyuat, Karangampel, Krangkeng. sedangkan hanya ada 1 kecamatan yang masuk agak rawan pangan (prioritas 3) yaitu kecamatan Indramayu. Dalam mengantisipasi kerentanan pangan di Kabupaten Indramayu perlu diberlakukan program antisipasi rawan pangan dari pemerintah atau pihak yang terkait agar kerawanan pangan dapat diantisipasi sedini mungkin. Indikator-inkator ketahanan pengan perlu jadi perhatian khusus, dan sesegera mungkin 
MIMBAR Agama Budaya, 36 (2), 2019

dilakukan kebijakan agar tidak menjadi permasalahan yang lebih besar terhadap gizi buruk, status kesehatan bahkan pertumbuhan ekonomi.

\section{Daftar Pustaka}

Badan Pusat Statistik, 2016. Online https://www.bps.go.id

Dewan Ketahanan Pangan, Kementerian Pertanian dan World Food Programme (WFT). Peta Ketahanan dan Kerentanan Pangan Indonesia 2015. (Jakarta: 2015)

Kementerian Pertanian Republik Indonesia, Rencana Strategis Kementerian Pertanian (Renstra) Tahun 2015-2019, (Jakarta: 2015)

Sakernas Badan Pusat Statistik. 2017. Online www.bps.go.id

Sugiyono. 2013. Metode Penelitian Pendidikan (Metode Penelitian Kuantitatif, Kualitatif dan R\&D). Bandung: Alfabeta

Wawancara dengan Imam Mahdi, Sp. MM. Kabid Analisis Ketahanan Pangan, 25 Juni 2018 di Kantor Dinas Ketahanan Pangan Kab. Indramayu 